hypothesis is, then, the true one, and the inner surface is electrified positively.

The explanation of both the direct and inverse rotation follows naturally from these facts and those communicated in my former note. For since the inner surface, when exposed to luminous or calorific radiations, is electrified positively, the direct rotation is a necessary consequence of the attractions and repulsions which this positive electricity exerts upon the free electricity of the vanes. This rotation continues when the radiometer is surrounded by light, because a perfectly homogeneous layer of electricity upon the inner surface is almost impossible.

The inverse rotation occurs in two circumstances-

I. When the instrument, having been exposed to radiation which produces a direct rotation is allowed to cool slowly.

2. When the radiometer at the ordinary temperature is cooled suddenly, for instance, by moistening it with ether.

In the first case, the electricity which the globe acquires when exposed to radiation disappearing very slowly, as experiments show, an inversion of the movement can be produced by an inversion in the signs of the electricity of the vanes. In fact, in accordance with the principle of reciprocity, the emission of the radiations gives rise in the vanes to a development of electricity equivalent and contrary to that which absorption has produced there. By this development of electricity the vanes would return to their neutral state if the electricity produced by absorption had not passed in part from the vanes into the rarefied gas of the globe. Now this passage took place with a greater energy as the rotary movement of the vanes had renewed more frequently the mass of air in contact with them. Hence the electric effect of the emission will be to change the signs and to dininish the charge of free electricity of the vanes.

In the second case, where the cooling is produced by moistening the exterior, the globe remains in its neutral state. For, as I have above remarked, during the whole time of the inverse rotation, the cooled surface of the globe gives no signs of electricity. It appears that the cooling itself is not capable of producing electricity, but that the passage of a radiation through the surface is absolutely required. In these conditions the vanes become charged with negative electricity upon the dark, and positive upon the bright side, by reason of the emission, at the same time that the radiations given forth by the vanes and $a b$. sorbed by the inner surface of the glass globe electrify the latter positively.

Thus the electric theory of the radiometer explains quite well the principal phenomena which have been observed up to the present time. I hope to make, hereafter, a study of all the particular movements which different observers have noted in the accounts of their experiments. I will only say now that the most remarkable of them, viz., the rotation of the radiometer globe, when an obstacle is put to the rotation of the vanes, as discovered by Schuster, is in entire conformity with the above theory, while it constitutes a very serious objection to the hypothesis of mechanical impulsion by radiation.

Joseph DeLsaulX, S.J.

II, rue des Récollets, Louvain

\section{A Rudimentary Tail}

A DAY or two ago a curious and interesting abnormality came under my notice, which, I think, deserves mention. I was examining the back of a girl, aged about eight, when $I$ saw over the lower part of the sacrum, in the middle line of the back, a small hole, that, on the first glance, seemed like the opening of an old sinus. I was told, however that it had been present since birth, and I then looked at it more carefully. It had a direction downwards and somewhat forwards, and consisted of a reflection of the skin entering a more or less circular depression, about $\frac{1}{3}$ inch in diameter, and about $\frac{1}{4}$ inch deep. Not quite $\frac{1}{4}$ inch below its lower border could be felt the pointed extremity of the coccyx, which, instead of having its usual form, curved backwards and rather upwards. On stretching the skin downwards, that portion of it entering the depression or hole was raised, coming out like the top part of the finger of a glove which had been pressed down into the lower part, and a small prominence, about the height of the diameter of a pea, stood up from the surface; and this little sheath was found to cover and exactly fit the sharp end of the coccyx. The resemblance this bore to a rudimentary tail was sufficientiy striking.

Jersey

ANDREW DUNLOP
The Aolian Fornation on the Lancashire Coast

IN the absence of large works on the subject, has your recent Waterloo correspondent seen the Survey memoir of the district around Southport in which the phenomena of wind dififtage are treated in a brief yet quantitative manner? The efficient way in which pebbles and shells-as of Mactra stultorum (with which the shore is so plentifully covered)-especially when the convex side of a valve is presented vertically towards the direction of the storm winds, protect a small area to leewaró, forming a miniature crag-and-tail arrangement, would seem to suggest that a solid screen offering an unbroken surface to the action of the wind, and at some distance from the region threatened, would be far more useful than the present expedients of growing marram grass, \&c., to consolidate the dunes, or of planting lines of bare stakes. Practical men would easily devise a cheaply constructed barrier of old ship-timber faced with ling or other accessible material, or perhaps use the sand-hills themselves when armoured with tabular blocks of stone made on the spot by some such pro. cess as employed in the construction of the sea-walls of the Suez Canal. Land sold for building plots on exposed points ought surely to have some adequate defence against the devouring sand.

Manchester, Sept, I5

WILLIAM GEE

\section{OUR ASTRONOMICAL COLUMN}

THE TOTal SOLAR ECLIPSE OF 1885 , SEPT. 8-9.The following elements, though approximate only, will suffice to give a pretty fair indication of the circumstances under which the totality of this eclipse will take place :-

Conjunction in R.A., r885, Sept. 8, at 9h. $18 \mathrm{~m} .58 \mathrm{~s}$. G.M.T.

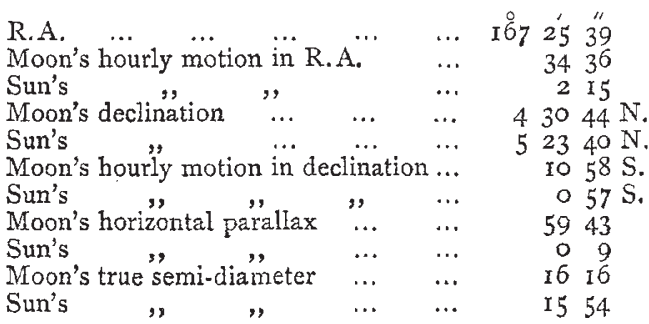

Hence the central and total eclipse begins upon the earth in long. $156^{\circ} 54^{\prime} \mathrm{E}$., lat. $40^{\circ} 54^{\prime} \mathrm{S}$., and ends in long. $75^{\circ} 33^{\prime} \mathrm{W}$., Iat. $74^{\circ} 38^{\prime} \mathrm{S}$., and the sun is centrally eclipsed at apparent noon in long. $138^{\circ} 39^{\prime}$ W., lat. $57^{\circ} 40^{\prime} \mathrm{S}$.

The following are also points upon the central line :-

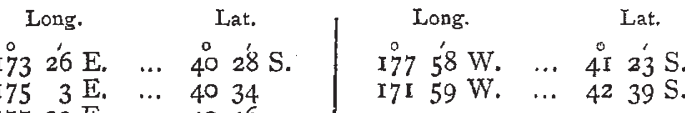

... 4034

The semi-diameter of the shadow in these longitudes is about $55^{\prime}$. It would therefore appear that observations are not likely to be made to any useful purpose, except in the southern part of the northern island of New Zealand, and here the sun will have no great elevation above the horizon. If we calculate from the above elements directly for Wellington, assuming the longitude of this place IIh. 39m. 20s: E., and its latitude $4 \mathrm{I}^{\circ} \mathrm{I} 7^{\prime}$, we find-

h. m. s.

Partial eclipse begins Sept. 9 at 6 r 8 o A.M. ) Mean times

Total ", begins ", 74222 " $\quad \begin{array}{r}\text { Mean time at } \\ \text { at }\end{array}$

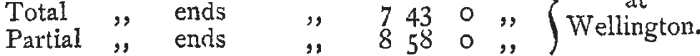

And therefore the duration of totality 38 seconds oniy, with the sun at an altitude of $55^{\circ}$.

Calculating similarly for one of the points upon the central line, some fifty miles north of Wellington, or long. $175^{\circ} 3^{\prime} \mathrm{E}$, lat. $40^{\circ} 34^{\prime}$, the totality is found to commence at $7 \mathrm{~h}$. $4 \mathrm{Im}$. 3 Is. A.M., local mean time, and to con. tinue $1 \mathrm{~m}$. 54s., with the sun at an altitude of $16^{\circ}$.

At Wellington the sun rises at $6 \mathrm{~h} .2 \mathrm{Im}$. 
An Intra-Mercurial Planet (?).-A second letter from Prof. Rudolph Wolf, of Zurich, giving further particulars relating to $M$. Weber's observations at Peckeloh, near Münster, on April 4, I876, was communicated by M. Leverrier to the Paris Academy on the Irth inst. The sky had been cloudless up to noon, and neither spot nor facula was remarked, though the sun's disk was examined three or four times, according to M. Weber's custom. After noon the sky clouded until between $4^{\mathrm{h}}$ and $5^{\mathrm{h}}$, when it cleared in places, and the sun was visible from twenty to twenty-five minutes. Utilising this interval, " $M$. Weber ne vit pas defacule, quoiqu'il eût promené la lunette sur toute la circonférence du soleil. Tout à coup un petit disque bien arrondi de 12 secondes d'arc se montra. Il se trouvait à I I secondes de temps du bord oriental, et à la même distance au nord de l'equateur céleste (sic). L'astronome eut le temps d'examiner de très-près le voisinage de la tache, et nulle part il n'aperçut le plus imperceptible mouvement de facule, nulle part un nuage avoisinant. Seul le petit disque foncé se détachait sur le fond solaire."

The sky soon after clouded, and it was only at five o'clock on the following morning that it was possible to ascertain that "the phenomenon had disappeared from the surface of the sun." The Peckeloh observation was made at 4 h. $25 \mathrm{~m}$. P.M., mean time at Berlin. It will be remarked that the observation leaves something to be desired as regards clearness.

The Isi, 2nd, and 3 rd of next month are dates when it is desirable the sun's disk should be closely examined for any abnorinal spot.

\section{THE BRITISH ASSOCIATION}

MIONG the later discussions of the meeting no doubt that which has excited most general notice was the debate on Prof. Barrett's paper "On Certain Abnormal Conditions of Mind." There can be little question that in one sense it dealt with subjects suitable for the department of Anthropology, and the scientific repute of Mr. Crookes, Mr. Wallace, Lord Rayleigh, and Prof, Barrett, necessitates the careful examination of anything they may bring forward. But it is doubtful whether the interests of science are best served by the introduction of subjects which are sure to provoke heated and unscientific discussion at a mixed meeting like that of the Association. Dr. McCann did not obtain very much favour for his ill-judged and extravagant scheme of endowed research which he propounded. A good suggestion was throwi out by one of the foreign visitors at the Lord Provost's spendid banquet to the principal members of the Association, in favour of close union and inter-communication between the British and similar Associations in other countries.

The General Committee passed the following resolution relative to the proposed museum of scientific instruments:- "That the Council be requested to take steps to urge upon her Majesty's Government the advisability of forming a museum of scientific instruments and chemical products, as suggested in the memorial of June last to the Lord President of the Council." The Committee also approved a recommendation that in future the presidents-elect of the various sections be invited to confer with the general secretaries, preparatory to the issue of the first number of the daily fournal at each meeting, to arrange the order in which the sectional addresses shall be delivered. Thus members may have an opportunity of hearing more than one sectional address.

The following is a list of the grants made at this meeting for scientific purposes; the name prefixed is in each case that of the person entitled to call upon the treasurer for the amount:-
Mathematics and Physics.

$a$ Everett, Prof.-Underground Temperature

$a$ Stokes, Prof.--Reflective Powers of Silver and other Substances (renewed)

Thomson, Sir William.-Measurement of the Lunar Dis-

$\begin{array}{cccccccc}\text { turbance of Gravity } & \ldots & \ldots & \ldots & \ldots & \ldots & \ldots & \ldots \\ a \text { Tait, Prof. -Thermoelectricity (renewed) } & \ldots & \ldots & \ldots & \ldots\end{array}$ $a$ Cayley, Prof.-Publication of Tables of Elliptic Functions ..

ajoule, Dr.-Determination of the Mechanical Equivalent $\begin{array}{llllllllll}\text { of Heat } & \ldots & \ldots & \ldots & \ldots & \ldots & \ldots & \ldots & \ldots & \ldots\end{array}$

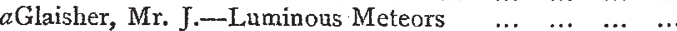

Forbes, Prof. G.-Observation of Atmospheric Electricity $\begin{array}{llllllllll}\text { in India } & \ldots & \ldots & \ldots & \ldots & \ldots & \ldots & \ldots & \ldots & \ldots\end{array}$ Chemistry.

aAllen, $\mathrm{Mr}$ - Estimation of Potash and Phosphoric Acid.. Wallace, Dr. W.-Light from Coal Gas ... ... ... ... aClowes, Dr. F.-Action of EthyI Bromo-Butyrate on Ethyl Sodaceto-acetate (renewed)

aArmstrong, Prof.-Isomeric Cresols and the Law of Substitution in the Phenol Series (renewed)

Hartley, Mr. W. N.-Double Compounds of Cobait and Nickel

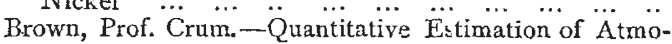
spheric Ozone...

Hartley, W. N.-Liquid Carbonic Acid in Minerals ... Geology.

$a$ Evans, Mr. J.-Kent's Cavern Exploration $a$ Lubbock, Sir J., Bart.-Exploration of Victoria Cave, Settle

aEvans, Mr. J.--Record of the Progress of Geolngy $\ldots$ a Hull, Prof.-Underground Waters in the New Red Sand. stone and Permian

a Herschel, Prof. - Thermal Conductivities of Rocks $\ldots \ldots$

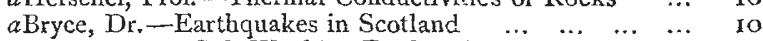

Topley, Mr. -Sub.Wealden Exploration $\ldots$... $\ldots$. .

$$
\text { Biology. }
$$

Gamgee, Prof.--Physiological Action']of Ortho-, Pyro-, and Metaphosphoric Acids

Hooker, Dr.-Report on the Family of the DipteroCarpeze

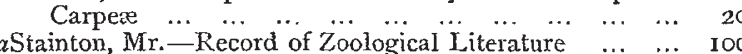

a Huxley, Prof. - Table at the Zoological Station at $\begin{array}{llllllllllll}\text { Naples } & \ldots & \ldots & \ldots & \ldots & \ldots & \ldots & \ldots & \ldots & \ldots & \ldots & 75\end{array}$

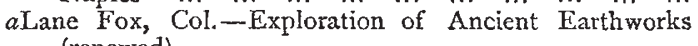
(renewed)

Lane Fox, Col._- Instructions for the Use of Travellers...

Statistics and Economic Science.

aFarr, Dr.-Anthropometric Committee (partly renewed). 100 aHubbard, Right Hon. J. G.-Common Measure of Value in Direct Taxation ...

\section{Mechanics.}

aFroude, Mr. W.-Instruments for Measuring the Speed

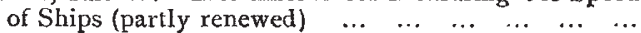
Thomson, Sir William - Secular Experiments on the

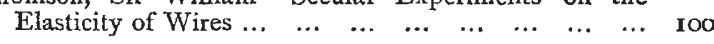

\section{$a$ Reappointed.}

At the concluding general meeting $M$ r. Griffith read the list of grants, and stated that $2,73 \mathrm{I}$ tickets had been sold, producing $2,983 l$. In detail, there had been present $21 \mathrm{I}$ old life members, $3 \mathrm{r}$ new life members, 318 old annuai members, 208 new annual members, I,243 associates, 696 ladies, and 24 foreign members. Sir John Hawkshaw moved a general vote of thanks to the local authorities and officials, especially mentioning Lord Provost Bain, Sir James Watson, Mr. Grahame, Dr. Blackie, and Mr. J. R. Napier. He said that the Lord Provost's kindness and geniality of disposition, his intelligence, and his power of unlimited work, were most remarkable. Capt. Galton, in seconding the motion, said he had never come in contact with a more energetic local committee. 